\title{
Evaluation of the impacts of aquaculture and freshwater habitat on the status of Atlantic salmon stocks in Ireland
}

\author{
David Jackson*, Tom McDermott, Frank Kane, Pauline O'Donohoe, Suzanne Kelly \\ Marine Institute, Galway, Ireland; *Corresponding Author: dave.jackson@marine.ie
}

Received 22 April 2013; revised 23 May 2013; accepted 10 June 2013

Copyright (c) 2013 David Jackson et al. This is an open access article distributed under the Creative Commons Attribution License, which permits unrestricted use, distribution, and reproduction in any medium, provided the original work is properly cited.

\begin{abstract}
Atlantic salmon (Salmo salar) returns to rivers in Ireland have fallen in the last decade resulting in the dramatic closure or curtailment of traditional fisheries. Concerns that stocks were slow to recover prompted further investigation of all factors believed to impact on salmon. In examining geographic and temporal trends in Atlantic salmon stock abundance at a River Basin District level, the effect of salmon aquaculture sites and freshwater habitat quality as potential drivers of stock abundance are evaluated. This study found no correlation between the presence of aquaculture and the performance of adjacent wild salmon stocks. Freshwater habitat quality was found to have a highly significant correlation with stock status, suggesting that it may be a key driver, implicated in the survival of individual stocks.
\end{abstract}

Keywords: Aquaculture; Atlantic Salmon; Marine Survival; Habitat Quality; Sea Lice; Escapees

\section{INTRODUCTION}

Stock levels of Atlantic salmon in the Northeast Atlantic had been declining since the 1970s prompting studies into possible factors affecting survival, including climate change [1-4], overexploitation [5,6], by-catch in commercial marine fisheries [7,8], predation [9], freshwater habitat quality [10-12] and aquaculture [13-16]. In Ireland marine survival, as presented by the Standing Scientific Committee on the Status of Irish Salmon Stocks [17] shows a general downward trend from the mid 1980s to 2008 (Figure 1) which is attributed to "very poor marine conditions leading to poor survival". Other potential factors that may contribute to the observed reduction are
Aquaculture and Freshwater Habitat.

Sea lice (Lepeophtheirus salmonis) levels on returning wild Atlantic salmon off the coast of Ireland regularly approach $100 \%$ prevalence, with a mean abundance of 10.9 L. salmonis per fish. Significant numbers of returning wild salmon remain in coastal and estuarine waters off Ireland's west coast for sufficient periods to be both the source of, and subject to, infestation with $L$. salmonis [18]. A number of investigations in the last decade have focussed on the impacts of sea lice on outwardly migrating salmon along Ireland's coastline [19-22]. To determine what impact such levels of lice have on salmon migrating to sea as post smolts, a large scale metaanalysis involving 352,142 salmon was undertaken from 2001 to 2009 at 8 locations along Ireland's south and west coasts [22]. The results suggest the observed level of marine mortality attributable to sea lice is small in absolute terms (approximately 1\%), and as a proportion of the overall marine mortality [22]. At the levels found it is unlikely to influence the conservation status of stocks and is neither a significant driver of marine mortality nor has been implicated in the observed decline in

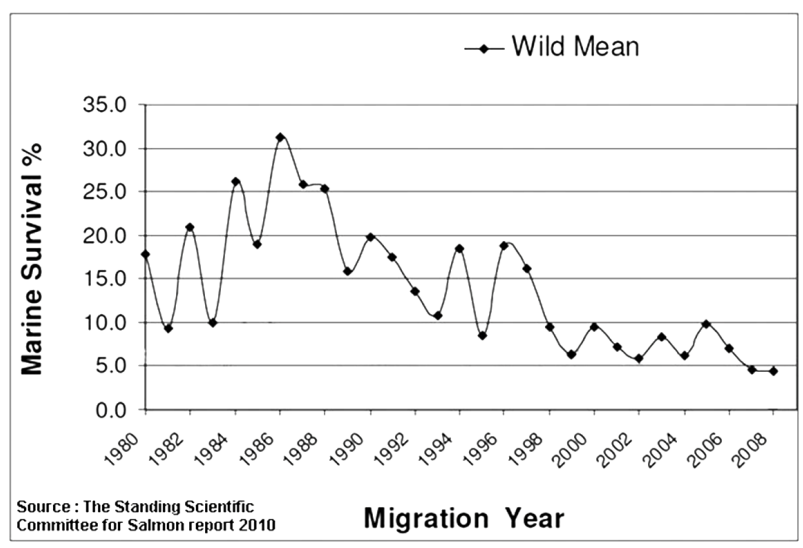

Figure 1. Marine survival (from smolt release to adult returns to the coast of Ireland) for wild salmon [17]. 
marine survival in the stocks studies [19]. These results are consistent with a Norwegian research that generated broadly similar findings [23].

Rivers in Ireland are divided into seven River Basin Districts for administrative purposes with Conservation Limits established for each salmon river from 2007 [17]. Conservation Limits for stocks are based on reaching escapement targets of spawning fish into rivers that allow for a sustainable harvest of salmon into the future. Conservation limits for salmon stock complexes may therefore be defined as "the level of stock (number of spawners) that will achieve long-term average maximum sustainable yield (MSY)". The status of salmon stocks in each river is assessed based on meeting their Conservation Limit, and is classified as Open, Catch \& Release (C\&R) or Closed. There is significant variability in stock status between River Basin Districts. Such geographical variability points to near field factors are implicated in influencing stock status.

In examining geographic and temporal trends in stock abundance of Atlantic salmon at a River Basin District level, the authors are seeking to evaluate the effect of salmon aquaculture sites and fresh water habitat quality as potential drivers of stock abundance.

\section{MATERIALS AND METHODS}

Published national statistics were examined to evaluate stock status on a catchment and River Basin District basis. Conservation limits and stock status, including surplus above Conservation Limits available for exploitation for each salmon river, was sourced from the reports of the Standing Scientific Committee to the Department of Communications, Energy and Natural resources [24-27]. Where rivers are meeting, or exceeding, their Conservation Limits, this surplus is available for exploitation by angling and commercial fisheries (i.e. the rivers are open).

The locations and active salmon aquaculture sites was obtained from the series of annual reports on the results of the National Survey of sea lice Lepeophtheirus salmonis Kroyer and Caligus elongatus Nordmann on fish farms in Ireland [28-30].

Water quality data was obtained from the Environmental Protection Agency (EPA). River water quality was classified by percentage of channel length meeting Class A unpolluted standard [31].

River Basin Districts are the administrative areas into which inland waters are divided for the purpose of management under the European Union's Water Framework Directive (WFD: 2000/60/EC). The proportion of these rivers meeting their Conservation Limits was established for each year. Salmon rivers with a population of less than ten salmon were excluded from the analysis.

\section{RESULTS}

Table 1 presents the data on rivers open for exploitation, including the taking of fish and on a catch and release basis. There is an increase in the rivers open nationally from 42 in 2007 to 48 in 2011. When broken down by River Basin District the trend is similar with numbers open either remaining static or increasing. The total number of rivers assessed varies slightly from year to year. This is a feature of the reports and arises due to sub-catchments being classified differently from time to time. Figure 2 shows the proportion of rivers either Open, C\&R or Closed in each River Basin District by year, including locations of active fish farm sites.

The same data is also presented as the proportions of fluvial area accessible to salmon (Figure 3) with commercial draft net fishing on open rivers highlighted. The West and Southwest River Basin Districts have consistently the highest proportion of rivers open throughout the period; the results are similar when expressed in terms of fluvial area accessible to salmon. The next highest proportion of rivers open is in the Northwest River Basin District.

There is no geographic correlation between the presence of salmon farms and failure of rivers to meet their Conservation Limits at a River Basin District level. In fact, the rivers in the River Basin Districts with salmon farms have performed best in terms of meeting their Conservation Limits and also in terms of ability to support a commercial catch by way of a commercial draft net fishery (Figure 3).

The percentage of channel length in each River Basin District meeting Class A unpolluted status is plotted for each River Basin District against the percentage of rivers meeting their conservation objective in each district (Figure 4). A significant geographical correlation exists between water quality in the catchment as measured by percentage Class A channel length and percentage of rivers meeting Conservation Limit $\left(\mathrm{R}^{2}=89.1 \%, \mathrm{p}=\right.$ $0.001)$.

\section{DISCUSSION}

The data presented here shows that the Conservation Limits are being met in many Irish salmon rivers and that there is a steady and sustained improvement in the overall status of Irish salmon stocks. The rivers on the West coast are in general better in this regard, and rivers in the Northwest, West and Southwest River Basin Districts support both angling and commercial draft net fisheries. There is no relationship between the presence of salmon farms and difficulties with rivers meeting their Conservation Limits. Numerous studies point to the fact of sea lice not being a factor in declining marine survival of wild salmon. The absence of any evidence for a negative correlation between salmon stock status and aquaculture 
Table 1. Salmon rivers open for exploitation, including catch and release, by River Basin District. Where rivers are open they are above their Conservation Limit, where they are C\&R (catch and release of fish caught) they are close to their Conservation Limit [24,27] (Source: Conservation of salmon and sea trout bye-laws as published annually by the Department of Communications, Marine and Natural Resources in Ireland).

\begin{tabular}{|c|c|c|c|c|c|c|c|c|}
\hline \multicolumn{2}{|c|}{ River Basin District } & \multicolumn{4}{|c|}{ Number of Rivers } & \multicolumn{3}{|c|}{ Percentage of Rivers (\%) } \\
\hline & Year & Open & $C \& R$ & Closed & Total & Open & $C \& R$ & Closed \\
\hline \multirow[t]{5}{*}{ Northwest } & 2007 & 9 & 0 & 6 & 15 & 60 & 0 & 40 \\
\hline & 2008 & 7 & 0 & 8 & 15 & 47 & 0 & 53 \\
\hline & 2009 & 8 & 0 & 7 & 15 & 53 & 0 & 47 \\
\hline & 2010 & 8 & 2 & 5 & 15 & 53 & 13 & 33 \\
\hline & 2011 & 9 & 2 & 3 & 14 & 64 & 14 & 21 \\
\hline \multirow[t]{5}{*}{ West } & 2007 & 16 & 4 & 4 & 24 & 67 & 17 & 17 \\
\hline & 2008 & 17 & 5 & 1 & 23 & 74 & 22 & 4 \\
\hline & 2009 & 15 & 5 & 2 & 22 & 68 & 23 & 9 \\
\hline & 2010 & 18 & 4 & 1 & 23 & 78 & 17 & 4 \\
\hline & 2011 & 17 & 5 & 1 & 23 & 74 & 22 & 4 \\
\hline \multirow[t]{5}{*}{ Shannon } & 2007 & 2 & 0 & 4 & 6 & 33 & 0 & 67 \\
\hline & 2008 & 2 & 0 & 3 & 5 & 40 & 0 & 60 \\
\hline & 2009 & 2 & 0 & 3 & 5 & 40 & 0 & 60 \\
\hline & 2010 & 2 & 0 & 3 & 5 & 40 & 0 & 60 \\
\hline & 2011 & 2 & 0 & 3 & 5 & 40 & 0 & 60 \\
\hline \multirow[t]{5}{*}{ Southwest } & 2007 & 14 & 0 & 6 & 20 & 70 & 0 & 30 \\
\hline & 2008 & 15 & 4 & 2 & 21 & 71 & 19 & 10 \\
\hline & 2009 & 19 & 3 & 4 & 26 & 73 & 12 & 15 \\
\hline & 2010 & 19 & 0 & 5 & 24 & 79 & 0 & 21 \\
\hline & 2011 & 16 & 5 & 1 & 22 & 73 & 23 & 5 \\
\hline \multirow[t]{5}{*}{ Southeast } & 2007 & 0 & 2 & 2 & 4 & 0 & 50 & 50 \\
\hline & 2008 & 0 & 3 & 3 & 6 & 0 & 50 & 50 \\
\hline & 2009 & 0 & 3 & 3 & 6 & 0 & 50 & 50 \\
\hline & 2010 & 1 & 2 & 2 & 5 & 20 & 40 & 40 \\
\hline & 2011 & 2 & 1 & 2 & 5 & 40 & 20 & 40 \\
\hline \multirow[t]{5}{*}{ East } & 2007 & 0 & 0 & 2 & 2 & 0 & 0 & 100 \\
\hline & 2008 & 0 & 1 & 2 & 3 & 0 & 33 & 67 \\
\hline & 2009 & 0 & 1 & 2 & 3 & 0 & 33 & 67 \\
\hline & 2010 & 0 & 1 & 2 & 3 & 0 & 33 & 67 \\
\hline & 2011 & 0 & 1 & 2 & 3 & 0 & 33 & 67 \\
\hline \multirow[t]{5}{*}{ Neagh-Bann } & 2007 & 1 & 1 & 2 & 4 & 25 & 25 & 50 \\
\hline & 2008 & 1 & 1 & 2 & 4 & 25 & 25 & 50 \\
\hline & 2009 & 1 & 1 & 2 & 4 & 25 & 25 & 50 \\
\hline & 2010 & 1 & 1 & 2 & 4 & 25 & 25 & 50 \\
\hline & 2011 & 2 & 1 & 1 & 4 & 50 & 25 & 25 \\
\hline \multirow[t]{5}{*}{ National } & 2007 & 42 & 7 & 26 & 75 & 56 & 9 & 35 \\
\hline & 2008 & 42 & 14 & 21 & 77 & 55 & 18 & 27 \\
\hline & 2009 & 45 & 13 & 23 & 81 & 56 & 16 & 28 \\
\hline & 2010 & 48 & 10 & 20 & 78 & 62 & 13 & 26 \\
\hline & 2011 & 48 & 15 & 13 & 76 & 63 & 20 & 17 \\
\hline
\end{tabular}



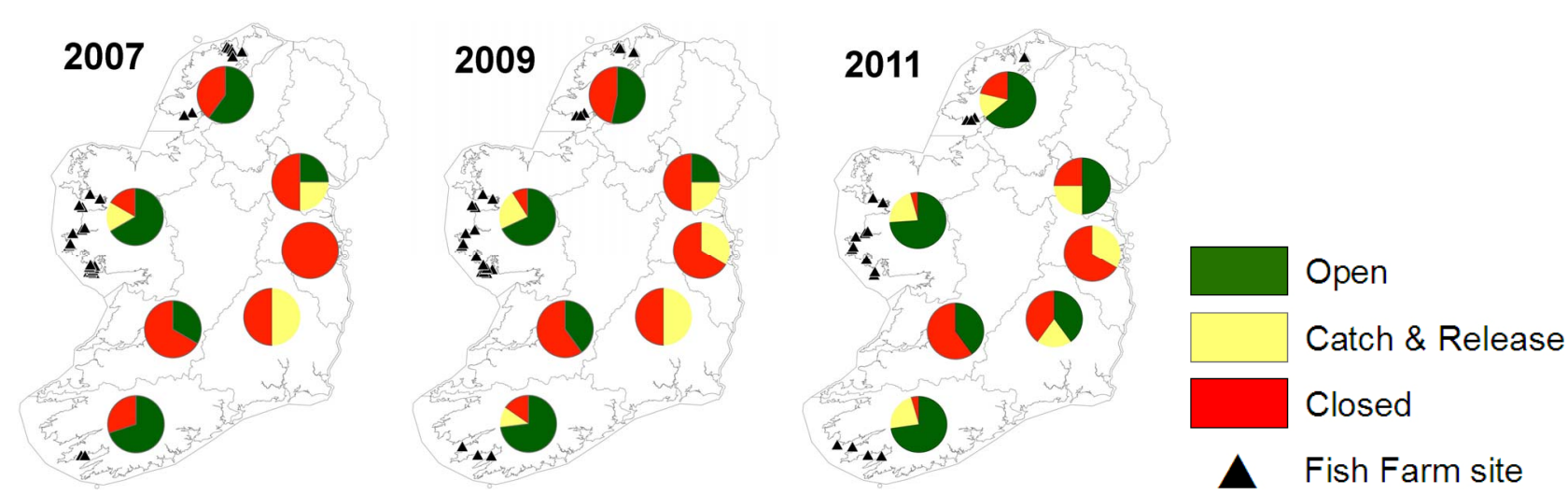

Figure 2. Map showing the proportion of rivers in each River Basin District which are open for fishing, being fished on a Catch \& Release basis or closed to exploitation [24-27]. Locations of salmon farm sites operational in each year [29-31] are indicated. (Source: Conservation of salmon and sea trout bye-laws as published annually by the Department of Communications, Marine and Natural Resources in Ireland).
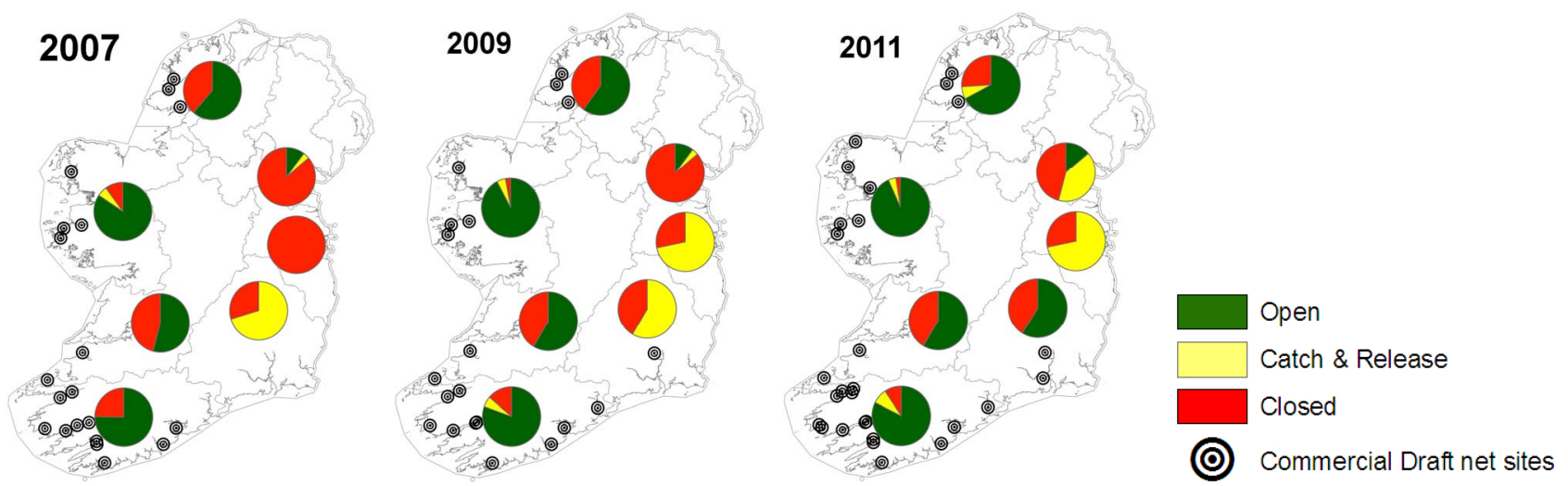

Figure 3. Map showing the proportion of rivers, measured as fluvial area accessible to salmon ( $\mathrm{m}^{2}$ ), in each River Basin District which are open for fishing, being fished on a Catch \& Release basis, or closed to angling [24-27]. Locations of commercial salmon draft net fishing sites are indicated. (Source: Conservation of salmon and sea trout bye-laws as published annually by the Department of Communications, Marine and Natural Resources in Ireland).

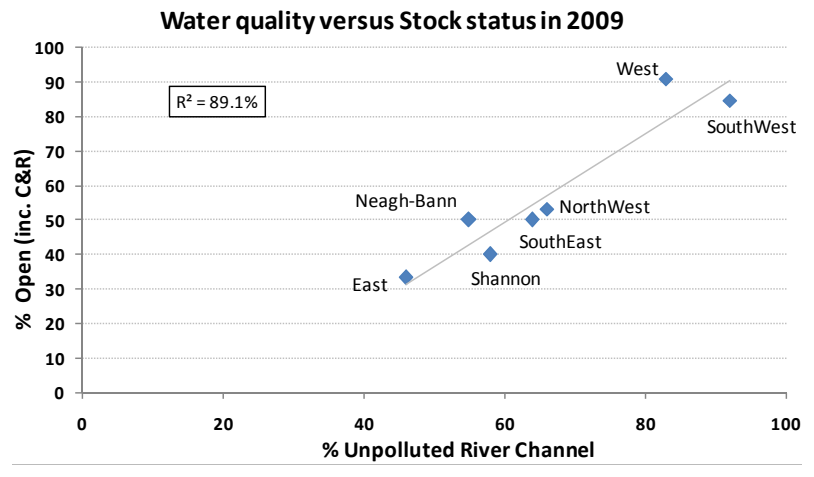

Figure 4. Relationship between salmon stock status as measured by percentage of rivers open for exploitation [24-27], and water quality of river channels [31] grouped by River Basin Districts. A regression line is fitted with $\mathrm{R}^{2}$ value indicated.

operations would suggest that there is also no discernible negative impact from escapees on the stocks studied. This conclusion is supported by the finding of O'Maoleidigh et al. [32] that fish farm escapees in Ireland are at a low level and contribute little to spawning stocks.

There is a significant correlation between unpolluted water quality in catchments and the numbers of rivers meeting their Conservation Limits (Figure 4). This correlation would suggest that the quality of freshwater habitat may be a key driver, implicated in the survival of individual wild salmon stocks.

Since the introduction of Conservation Limits in 2007 exploitation of salmon stocks has been reduced. The commercial offshore mixed-stock drift net fishery was closed since 2007. In addition angling pressure has been curtailed by closure of certain rivers, the introduction of Bye-Laws limiting catches and restrictions to angling for Spring salmon. The improvement of stock status over the study period would suggest that these conservation measures are contributing to stock recovery in a period of low marine survival.

\section{CONCLUSION}

This study found no correlation between the presence 
of aquaculture and the performance of adjacent wild salmon stocks. This finding supports previous research on farm escapees and sea lice which found little influence of escaped farmed salmon on spawning stocks [32], and sea lice were a minor and irregular component in marine mortality [22]. Freshwater habitat quality was found to have a highly significant correlation with stock status.

\section{REFERENCES}

[1] Friedland, K.D., Chaput, G. and MacLean, J.C. (2005) The emerging role of climate in post-smolt growth of Atlantic salmon. ICES Journal of Marine Science, 62, 13381349. doi:10.1016/j.icesjms.2005.04.013

[2] Friedland, K.D., MacLean, J.C., Hansen, L.P., Peyronnet, A.J., Karlsson, L., Reddin, D.G., Maoiléidigh, N.Ó. and McCarthy, J.L. (2009) The recruitment of Atlantic salmon in Europe. ICES Journal of Marine Science, 66, 289-304. doi:10.1093/icesjms/fsn210

[3] Peyronnet, L.A., Friedland, K.D., Maoileidigh, N.Ó., Manning, M. and Poole, W.R. (2007) Links between patterns of marine growth and survival of Atlantic salmon Salmosalar L. Journal of Fish Biology, 71, 684-700. doi:10.1111/j.1095-8649.2007.01538.x

[4] Todd, C.D., Hughes, S.L., Marshall, C.T., MacLean, J.C., Lonergan, M.E. and Biuw, E.M. (2008) Detrimental effects of recent ocean surface warming on growth condition of Atlantic salmon. Global Change Biology, 14, 958970. doi:10.1111/j.1365-2486.2007.01522.x

[5] Rago, P.J., Reddin, D.G., Porter, T.R., Meerburg, D.J., Friedland, K.D. and Potter, E.C.E. (1993) A continental run reconstruction model for the non-maturing component of North American Atlantic salmon: Analysis of fisheries in Greenland and Newfoundland-Labrador, 19741991. ICES Document, CM 1993/M: 25.

[6] Potter, E.C.E. and Dunkley, D.A. (1993) Evaluation of marine exploitation of salmon in Europe. In: Mills, D., Ed., Salmon in the Sea, and New Enhancement Strategies, Fishing News Books, Oxford, 203-219.

[7] Hansen, L.P., Holm, M., Hoist, J.C. and Jacobsen, J.A., (2003) The ecology of post-smolts of Atlantic Salmon Chapter 4. In: Salmon at the Edge, Blackwell Science Ltd., 25-39. doi:10.1002/9780470995495.ch4

[8] Mork, K.A., Gilbey, J., Hansen, L.P., Jensen, A.J., Jacobsen, J.A., Holm, M., Holst, J.C., Maoiléidigh, N.Ó., Vikebø, F., McGinnity, P., Melle, W., Thomas, K., Verspoor, E. and Wennevik, V. (2012) Modelling the migration of postsmolt Atlantic salmon (Salmosalar) in the Northeast Atlantic. ICES Journal of Marine Science, fss108v1-fss108.

[9] Butler, J.R.A., Middlemas, S.J., Graham, I.M., Thompson, P.M. and Armstrong, J.D. (2006) Modelling the impacts of removing seal predation from Atlantic salmon, Salmosalar, rivers in Scotland: A tool for targeting conflict resolution. Fisheries Management and Ecology, 13, 285291. doi:10.1111/j.1365-2400.2006.00504.X

[10] Gibson, R.J. (1993) The Atlantic salmon in fresh water: Spawning, rearing and production. Reviews in Fish Biol- ogy and Fisheries, 3, 39-73. doi:10.1007/BF00043297

[11] Mäki-Petäys, A., Huusko, A., Erkinaro, J. and Muotka, T. (2002) Transferability of habitat suitability criteria of juvenile Atlantic salmon (Salmosalar). Canadian Journal of Fisheries and Aquatic Sciences, 59, 218-228. doi:10.1139/f01-209

[12] Einum, S. and Nislow, K.H. (2011) Variation in population size through time and space: Theory and recent empirical advances from Atlantic salmon. In: Aas, Ø., Einum, S., Klemetsen, A. and Skurdal, J., Eds., Atlantic Salmon Ecology, Wiley-Blackwell, New York, 277-298.

[13] Crozier, W.W. (2000) Escaped farmed salmon, Salmosalar L., in the Glenarm River, Northern Ireland: Genetic status of the wild population 7 years on. Fisheries Management and Ecology, 7, 437-446. doi:10.1046/j.1365-2400.2000.00219.x

[14] Skilbrei, O.T. and Wennevik, V. (2006) Survival and growth of sea-ranched Atlantic salmon, Salmosalar L., treated against sea lice before release. ICES Journal of Marine Science, 63, 1317-1325. doi:10.1016/j.icesjms.2006.04.012

[15] Karlsson, S., Moen, T., Lien, S., Glover, K. and Hindar, K. (2011) Generic genetic differences between farmed and wild Atlantic salmon identified from a 7K SNP-chip. Molecular Ecology Resources, 11, 247-253.

[16] Glover, K.A., Quintela, M., Wennevik, V., Besnier, F., Sørvik, A.G.E., et al. (2012) Three decades of farmed escapees in the wild: A spatio-temporal analysis of Atlantic salmon population genetic structure throughout Norway. PLoS ONE, 7, e43129. doi:10.1371/journal.pone.0043129

[17] Anon (2010) Report of the standing scientific committee to the department of communications, energy and natural resources-The status of Irish salmon stocks in 2009 and precautionary catch advice for 2010. Department of Communications, Marine and Natural Resources, Dublin.

[18] Jackson, D., Kane, F., O’Donohoe, P., Mc Dermott, T., Kelly, S., Drumm, A. and Newell, J. (2013) Sea lice levels on wild Atlantic salmon, Salmosalar L., returning to the coast of Ireland. Journal of Fish Diseases, 36, 293298. doi:10.1111/jfd.12059

[19] Jackson, D., Cotter, D., O’Maoileidigh, N., O’Donohoe, P., White, J., Kane, F., Kelly, S., McDermott, T., McEvoy, S., Drumm, A., Cullen, A. and Rogan, G. (2011) An evaluation of the impact of early infestation with the salmon louse Lepeophtheirus salmonis on the subsequent survival of outwardly migrating Atlantic salmon, Salmosalar L., smolts. Aquaculture, 320, 159-163. doi:10.1016/j.aquaculture.2011.03.029

[20] Jackson, D., Cotter, D., O’Maoileidigh, N., O’Donohoe, P., White, J., Kane, F., Kelly, S., McDermott, T., McEvoy, S., Drumm, A. and Cullen, A. (2011) Impact of early infestation with the salmon louse Lepeophtheirus salmonis on the subsequent survival of outwardly migrating Atlantic salmon smolts from a number of rivers on Ireland's south and west coast. Aquaculture, 319, 37-40. doi:10.1016/j.aquaculture.2011.06.042

[21] Gargan, P.G., Forde, G., Hazon, N., Russell, D.J.F. and Todd, C.D. (2012) Evidence for sea lice-induced marine mortality of Atlantic salmon (Salmosalar) in western Ire- 
land from experimental releases of ranched smolts treated with emamectin benzoate. Canadian Journal of Fisheries and Aquatic Sciences, 69, 343-353. doi:10.1139/f2011-155

[22] Jackson, D., Cotter, D., Newell, J., McEvoy, S., O’Donohoe, P., Kane, F., McDermott, T., Kelly, S. and Drumm, A. (2013) Impact of Lepeophtheirus salmonis infestations on migrating Atlantic salmon, Salmosalar L., smolts at eight locations in Ireland with an analysis of lice-Induced marine mortality. Journal of Fish Diseases, 36, 273-281. doi:10.1111/jfd.12054

[23] Skilbrei, O.T., Finstad, B., Urdal, K., Bakke, G., Kroglund, F. and Strand, R. (2013) Impact of early salmon louse, Lepeophtheirus salmonis, infestation and differences in survival and marine growth of sea-Ranched Atlantic salmon, Salmosalar L., smolts 1997-2009. Journal of Fish Diseases, 36, 249-260. doi:10.1111/jfd.12052

[24] Anon (2007) Report of the standing scientific committee of the national salmon commission-The status of Irish salmon stocks in 2006 and precautionary catch advice for 2007. Department of Communications, Marine and Natural Resources, Dublin.

[25] Anon (2008) Report of the standing scientific committee of the national salmon commission-The status of Irish salmon stocks in 2007 and precautionary catch advice for 2008. Department of Communications, Marine and Natural Resources, Dublin.

[26] Anon (2009) Report of the standing scientific committee to the department of communications, energy and natural resources-The status of Irish salmon stocks in 2008 and precautionary catch advice for 2009. Department of Com- munications, Marine and Natural Resources, Dublin.

[27] Anon (2011) Report of the standing scientific committee for salmon to the department of communications, energy and natural resources-The status of Irish salmon stocks in 2010, with precautionary catch advice for 2011. Department of Communications, Marine and Natural Resources, Dublin.

[28] O’Donohoe, P., Kane, F., Kelly, S., Nixon, P., Power, A., Naughton, O. and Jackson, D. (2008) National survey of sea lice (Lepeophtheirus salmonis Krøyer and Caligus elongatus Nordmann) on fish farms in Ireland-2007. Irish Fisheries Bulletin No. 31, Marine Institute.

[29] O’Donohoe, P., Kane, F., Kelly, S., Nixon, P., Power, A., McDermott, T., Drumm, A. and Jackson, D. (2010) National survey of sea lice (Lepeophtheirus salmonis Krøyer and Caligus elongatus Nordmann) on fish farms in Ireland-2009. Irish Fisheries Bulletin No. 33, Marine Institute.

[30] O’Donohoe, P., Kane, F., Kelly, S., McDermott, T., Drumm, A. and Jackson, D. (2012) National survey of sea lice (Lepeophtheirus salmonis Krøyer and Caligus elongatus Nordmann) on fish farms in Ireland-2011. Irish Fisheries Bulletin No. 40, Marine Institute.

[31] McGarrigle, M., Lucey, J. and Ó’Cinnéide, M. (2010) Water quality in Ireland 2007-2009. EPA, Ireland, 138.

[32] O’Maoileidigh, N., Cullen, A., McDermott, T., Bond, N. and McLaughlin, D. (2002) Review of Irish salmon aquaculture escapee data. International Council for the Exploration of the Sea, Copenhagen. 